\title{
Genetic diversity and local population structure of fragmented populations of Trillium camschatcense (Trilliaceae)
}

\author{
Hiroshi Tomimatsu, Masashi Ohara* \\ Laboratory of Ecology and Genetics, Graduate School of Environmental Earth Science, Hokkaido University, Sapporo 060-0810, Japan
}

Received 8 March 2002; received in revised form 15 May 2002; accepted 16 May 2002

\begin{abstract}
Trillium camschatcense, a long-lived common woodland herb, has been experiencing intensive habitat fragmentation over the last century in eastern Hokkaido, Japan. We examined the genetic diversity and population genetic structure of 12 fragmented populations with different population sizes using allozyme electrophoresis. The percentage of polymorphic loci and mean number of alleles per locus were positively related to population size, probably due to the stochastic loss of rare alleles (frequency of $q<0.1$ ) in small populations. Populations with 350 flowering plants or fewer had lost almost all of their rare alleles. While the heterozygosity and inbreeding coefficient were not related to population size, some small populations showed relatively high inbreeding coefficients. In spite of the low genetic differentiation among overall populations $\left(F_{\mathrm{ST}}=0.130\right)$, local population structuring was recognized between the two geographically discontinuous population groups. Within groups, sufficient historical gene flow was inferred, whereas a low dispersal ability of this species and geographical separation could produce apparent differentiation between groups. (C) 2002 Elsevier Science Ltd. All rights reserved.
\end{abstract}

Keywords: Allozymes; Forest fragmentation; Genetic diversity; Population genetic structure; Population size; Trillium camschatcense

\section{Introduction}

The consequences of habitat fragmentation on plant populations have two aspects, a demographic aspect and a genetic aspect (Lande, 1988; Schemske et al., 1994). Lande (1988) emphasized demography as being of more immediate importance for long-term species viability, and many studies have concentrated on identifying ecological factors which affect population dynamics, including the disruptions of plant-pollinator interactions (e.g. Jennersten, 1988; Aizen and Feinsinger, 1994) and the changes of microclimatic conditions (e.g. Lovejoy et al., 1986; Laurance et al., 1998). However, recently, attention has been increasingly focused on the assessment of genetic attributes of remnant populations (e.g. review by Young et al., 1996) and its practical usefulness is now being discussed (e.g. Crandall et al., 2000; Sherwin and Moritz, 2000).

Theoretically, fragmentation is predicted to cause genetic erosion owing to founder effects, and subsequently to genetic drift and inbreeding (reviews by Barrett

\footnotetext{
* Corresponding author. Fax: +81-11-706-4525.

E-mail address: ohara@ees.hokudai.ac.jp (M. Ohara).
}

and Kohn, 1991; Ellstrand and Elam, 1993; Young et al., 1996). The genetic erosion induced by fragmentation may be harmful to population persistence, because reduced heterozygosity may lead to decreased individual fitness (Rajimann et al., 1994; Oostermeijer et al., 1995) and the loss of allelic richness may eliminate the opportunities for future adaptation (Frankel et al., 1995). The theory predicts positive relations of genetic diversity and heterozygosity to population size, and such relationships have been practically identified for some species which have recently experienced habitat loss (e.g. van Treuren et al., 1991; Prober and Brown, 1994). However, because the responses to fragmentation may vary depending on habitat or life history characteristics (Young et al., 1996), more studies on genetic consequences of fragmentation need to be conducted.

We are conducting a series of investigations exploring the demographic and genetic effects of forest fragmentation on a spring woodland herb, Trillium camschatcense Ker Gawler (Trilliaceae), in the Tokachi region of eastern Hokkaido, Japan. In this region, anthropogenic land conversion (e.g. road construction and agricultural development) since the 1880 s has resulted in a highly fragmented landscape with a large number of forest 
remnants, many of which are smaller than 1 ha (Tan, 1994). Trillium camschatcense commonly occurs in this region and sometimes forms large ( $>5 \mathrm{ha}$ ), continuous populations. This species is now often found in the understory of small remnant forests surrounded by pastureland or agricultural fields, and we can assume that forest fragmentation divided formerly huge $T$. camschatcense populations into small and isolated pieces. Accordingly, T. camschatcense in this region must have experienced dramatic changes in population size and spatial distribution, which may have significantly reduced genetic diversity and altered population genetic structure. Populations in the region are self-incompatible, and seed production results from outbreeding by insect pollination (Ohara et al., 1996). Self-incompatible plants are expected to be particularly vulnerable to genetic deterioration such as the loss of compatible mates (Byers, 1995) and increased inbreeding (Ellstrand and Elam, 1993).

Our previous study (Tomimatsu and Ohara, in press) showed that seed production and seedling recruitment was reduced in small, fragmented $T$. camschatcense populations. This study explores a genetic aspect of fragmentation. We assess the genetic diversity, levels of inbreeding, and population genetic structure based on allozyme variation, and discuss the genetic effects of fragmentation on $T$. camschatcense populations.

\section{Methods}

\subsection{Species and study sites}

Trillium camschatcense, a corrected name for $T$. kamtschaticum Pall. (Fukuda et al., 1996), is a diploid $(2 n=10)$, long-lived herbaceous perennial that mainly occurs in the understory of the broad-leaved deciduous forests of Hokkaido and northern Honshu, Japan. It takes more than 10 years for seedlings to become flowering plants, and after reaching flowering, the plants can live for at least 20 years with continuous flowering every year (Ohara and Kawano, 1986b). Reproductive plants of $T$. camschatcense produce single or sometimes a few flowers that arise from separate stems originated from the rhizome. Each flower has three large white petals and this species reproduces exclusively by seeds (Ohara and Kawano, 1986a). The flowers are generally visited by various insects mostly belonging to Diptera and Coleoptera (Ohara et al., 1991). In study populations, members of Nitidulidae, Melandryindae, Oedemeridae (Coleoptera), Scatophagidae, and Bibionidae (Diptera) were often observed (H. Tomimatsu et al., unpublished data).

Regarding population genetics of $T$. camschatcense, Kurabayashi (1957) divided populations of Hokkaido into three geographical regions, North, East, and South, based on chromosomal variations, and Ohara et al.
(1996) re-examined the patterns of genetic differentiation with isozymes. Both studies revealed that the populations of eastern Hokkaido where the present study was conducted show higher intra and interpopulation genetic diversity than the other geographical regions (Kurabayashi, 1957; Ohara et al., 1996). Ohara et al. (1996) also showed that the plants in eastern Hokkaido are self-incompatible, whereas plants in the other regions are self-compatible.

This study examines 12 populations with different population sizes in the Tokachi region of eastern Hokkaido (Fig. 1; Table 1). Population size, the estimated number of flowering plants, was determined by multiplying the population area by the flowering plant density (Table 1).

\subsection{Leaf sampling and electrophoresis}

At flowering in May 1998, leaf materials were sampled in each population except for the $\mathrm{OH}$ population where the samples were collected in May 2000. Over 40 flowering individuals were randomly sampled per population, except for two small populations TB and MB (Table 2). Leaves collected were placed on ice, transported to the laboratory and stored at $-80{ }^{\circ} \mathrm{C}$ prior to analysis by electrophoresis. Approximately 90 $\mathrm{mg}$ of leaf tissue from each individual plant was homogenized in $0.9 \mathrm{ml}$ extraction buffer made up of $0.1 \mathrm{M}$ Tris- $\mathrm{HCl}(\mathrm{pH} 8.0), 0.2 \mathrm{~g} / \mathrm{ml}$ glycerol, $63 \mathrm{mg} / \mathrm{ml}$ Tween $80,8 \mathrm{mM}$ dithiothreitol (DTT), $0.5 \%$ (v/v) $\beta$-mercaptoethanol, $0.40 \%(\mathrm{w} / \mathrm{v}) \beta$-nicotinamide adenine dinucleotide ( $\beta$-NAD), $0.45 \%(\mathrm{w} / \mathrm{v}) \beta$-nicotinamide adenine dinucleotide phosphate ( $\beta$-NADP), $0.3 \%(\mathrm{w} / \mathrm{v})$ bovine serum albumin, and 7\% (w/v) polyvinylpolypyrrolidone (PVPP; modified form of Shiraishi, 1988). After the homogenates were centrifuged (15000 rpm for $10 \mathrm{~min}$ at $\left.4{ }^{\circ} \mathrm{C}\right), 15 \mu \mathrm{l}$ of the resulting supernatant was used for polyacrylamide vertical slab gel electrophoresis. We preliminarily tested 14 enzymes, and then a total of six enzyme systems that consistently showed clear and interpretable banding patterns were examined: aspartate aminotransferase (AAT; E.C. 2.6.1.1), malate dehydrogenase (MDH; E.C. 1.1.1.37), glutamate dehydrogenase (GDH; E.C. 1.4.1.2), sorbitol dehydrogenase (SODH; E.C. 1.1.1.14), alcohol dehydrogenase (ADH; E.C. 1.1.1.1), and 6-phosphogluconate dehydrogenase (6PGDH; E.C. 1.1.1.44). The staining procedures were modified from Shiraishi (1988). We resolved 11 putative loci from the six enzyme systems and assumed mendelian inheritance of all loci based on banding patterns given the expected enzyme unit substructures.

\subsection{Data analyses}

Standard measures of genetic diversity including the percentage of polymorphic loci $(P)$, the mean number of 


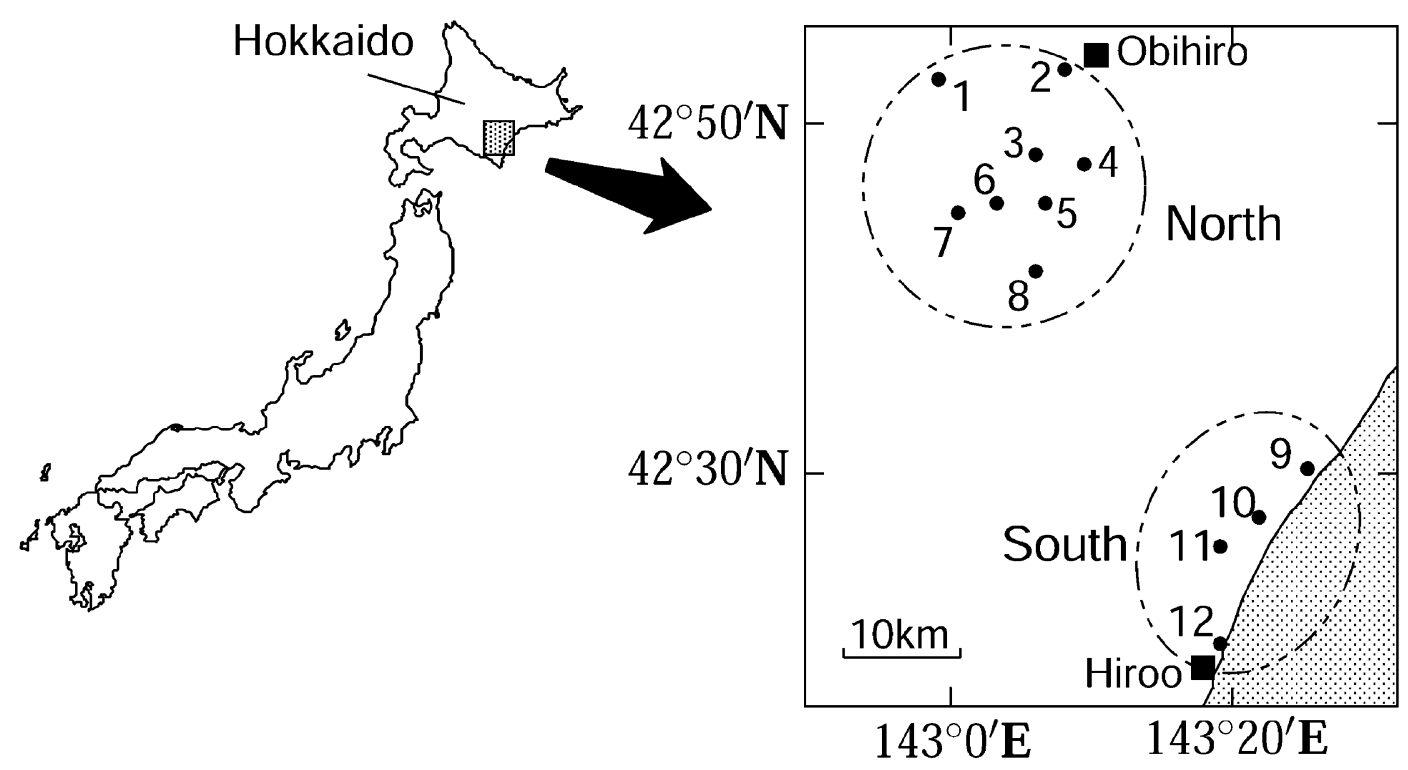

Fig. 1. Locations of the 12 Trillium camschatcense populations examined in the present study. Population numbers correspond to those in Table 1. Population groups inferred by a neighbor-joining (NJ) tree (Fig. 2) which corresponds to geographical pattern are also indicated by dashed circles.

Table 1

Trillium camschatcense populations examined in this study

\begin{tabular}{|c|c|c|c|c|c|}
\hline Population no. & Population (Abbreviation) & Population area $\left(\mathrm{m}^{2}\right)$ & Forest area $(\mathrm{ha})^{\mathrm{a}}$ & Flowering plant density ${ }^{\mathrm{b}}$ & Population size \\
\hline 1 & Shibusan (SS) & 550 & 0.19 & 10 & 220 \\
\hline 2 & Obihiro $(\mathrm{OH})$ & 1050 & 0.39 & 13 & 550 \\
\hline 3 & Motoimatsu (MM) & 18700 & 1.9 & 24 & 18000 \\
\hline 4 & Toyonishi (TN) & 3400 & 0.34 & 16 & 2200 \\
\hline 5 & Kiyokawa (KK) & 7700 & 1.0 & 33 & 10200 \\
\hline 6 & Hirono-kita (HK) & 1400 & 1.7 & 15 & 900 \\
\hline 7 & Hirono-minami (HM) & 5500 & 1.2 & 25 & 5500 \\
\hline 8 & Pepekiki (PK) & 1450 & 0.23 & 20 & 1200 \\
\hline 9 & Toberi (TB) & 190 & 0.019 & 6 & 46 \\
\hline 10 & Rekifune (RF) & 60000 & 31 & 64 & 153600 \\
\hline 11 & Monbetsu (MB) & 480 & 0.048 & 18 & 350 \\
\hline 12 & Hiroo (HI) & 50000 & 30 & 63 & 126000 \\
\hline
\end{tabular}

a Forest area was determined with aerial photographs.

b Average numbers of flowering plants in $25 \mathrm{~m}^{2}$ were calculated by randomly placing a $5 \times 5 \mathrm{~m}$ quadrat five times within each population.

alleles per polymorphic locus $\left(A_{\mathrm{p}}\right)$, the mean number of alleles per locus $(A)$, observed heterozygosity $\left(H_{\mathrm{o}}\right)$, and expected heterozygosity $\left(H_{\mathrm{e}}\right)$, were calculated for each population and for overall populations. Wright's (1951) $F$ statistics $\left(F_{\mathrm{IT}}, F_{\mathrm{ST}}\right.$, and $\left.F_{\mathrm{IS}}\right)$ were calculated for each polymorphic locus and for overall loci as Weir and Cockerham's (1984) estimates using the computer program FSTAT version 2.9.1 (Goudet, 2000), and the levels of significance were obtained by randomization based procedures [see Goudet (2000) for details]. Gene flow $(\mathrm{Nm})$ among populations was estimated indirectly from the population genetic structure using Wright's (1951) equation as modified by Crow and Aoki (1984): $F_{\mathrm{ST}}=$ $1 /(4 N m \alpha+1)$ where $\alpha=(n /(n-1))^{2}$ and $n$ is the number of populations. Slatkin's (1985) private allele method also provides equally effective estimates of $\mathrm{Nm}$ (Barton and Slatkin, 1986; Slatkin and Barton, 1989), though, we used only Wright's method because sampled populations showed only one private allele.

Genetic divergence among populations was also estimated by calculating Nei's (1972) standard genetic distance for all possible pairs of populations. The resulting distance matrix was used to build a neighbor-joining (NJ) dendrogram (Saitou and Nei, 1987) of which the reliability was tested by bootstrapping over loci (Felsenstein, 1985) and given as percentage values over 1000 replications. The DISPAN program (Ota, 1993) was used to carry out this analysis.

To test the effects of fragmentation, the relationships between population genetics parameters and the log of population size were explored with least-square linear regressions using the REG procedure of SAS version 
Table 2

Sample sizes, genetic diversity estimates, and inbreeding coefficients $\left(F_{\text {IS }}\right)$ for 12 Trillium camschatcense populations ${ }^{\mathrm{a}}$

\begin{tabular}{lllllllr}
\hline Population & $n$ & $P$ & \multicolumn{1}{l}{$A_{\mathrm{p}}$} & \multicolumn{1}{l}{$\mathrm{A}$} & \multicolumn{1}{l}{$H_{\mathrm{o}}$} & \multicolumn{1}{l}{$H_{\mathrm{e}}$} & \multicolumn{1}{l}{$F_{\mathrm{IS}}$} \\
\hline SS & 42 & 18.2 & 2.00 & 1.18 & 0.037 & 0.046 & 0.211 \\
OH & 44 & 54.5 & 2.33 & 1.73 & 0.105 & 0.100 & -0.043 \\
MM & 48 & 54.5 & 2.00 & 1.55 & 0.083 & 0.092 & 0.107 \\
TN & 48 & 54.5 & 2.00 & 1.55 & 0.057 & 0.054 & -0.056 \\
KK & 48 & 54.5 & 2.83 & 2.00 & 0.068 & 0.078 & $0.129^{*}$ \\
HK & 48 & 54.5 & 2.00 & 1.55 & 0.051 & 0.053 & 0.057 \\
HM & 48 & 54.5 & 2.00 & 1.55 & 0.034 & 0.035 & 0.034 \\
PK & 48 & 54.5 & 2.67 & 1.91 & 0.131 & 0.125 & -0.037 \\
TB & 24 & 18.2 & 2.00 & 1.18 & 0.083 & 0.081 & -0.004 \\
RF & 48 & 54.5 & 2.00 & 1.55 & 0.097 & 0.108 & 0.166 \\
MB & 31 & 18.2 & 2.50 & 1.27 & 0.067 & 0.080 & $0.257 *$ \\
HI & 40 & 81.8 & 2.33 & 2.09 & 0.132 & 0.133 & 0.072 \\
& & & & & & & \\
Mean & & 47.7 & 2.22 & 1.59 & 0.079 & 0.083 & 0.074 \\
(SE) & & $(5.6)$ & $(0.16)$ & $(0.09)$ & $(0.009)$ & $(0.009)$ & $(0.030)$ \\
Overall & 517 & 90.9 & 2.70 & 2.55 & 0.076 & 0.095 &
\end{tabular}

${ }^{\text {a }} n$, sample size; $P$, percent polymorphic loci; $A_{\mathrm{p}}$, mean number of alleles per polymorphic locus; $A$, mean number of alleles per locus; $H_{\mathrm{o}}$, observed heterozygosity; $H_{\mathrm{e}}$, expected heterozygosity (gene diversity); $F_{\mathrm{IS}}$, Weir and Cockerham's (1984) estimates of inbreeding coefficient; SE, standard error.

* Significant deviation of $F_{\text {IS }}$ from Hardy-Weinberg expectations at $P<0.05$ level obtained by randomization procedures.

6.12 (SAS Institute, 1997). In this study, the variation of sample sizes might affect genetic diversity estimates (especially allelic richness, $A$ ), because larger sample sizes could detect more alleles. Then we conducted a computer simulation to test whether reduced allelic diversity is due to differences in sample sizes. Each population sample was repeatedly reduced at random to 24 individuals, i.e. smallest sample size (Table 2), and we obtained the distribution of allelic richness among 1000 simulations. The simulation was not performed for the TB population with smallest sample size.

\section{Results}

\subsection{Genetic diversity and levels of inbreeding}

Ten of the 11 loci resolved $(90.9 \%$; Table 2) were polymorphic in at least one of the populations examined. In all the populations sampled, $6 P g d h$ was monomorphic. The percentage of polymorphic loci $(P)$ at the species level $(90.9 \%)$ was larger than a value, $65.5 \%$ for outcrossing long-lived perennial species (Hamrick and Godt, 1996). Levels of genetic diversity varied substantially among individual $T$. camschatcense populations. The percentage of polymorphic loci $(P)$ ranged from $18.2 \%$ (SS, TB, and $\mathrm{MB}$ ) to $81.8 \%(\mathrm{HI})$. The mean number of alleles per locus $(A)$ was 2.55 at the species level and 1.59 at the population level. The mean number of alleles per polymorphic locus $\left(A_{\mathrm{p}}\right)$ within populations was 2.22 with the KK population having the highest value (2.83).

Expected heterozygosity $\left(H_{\mathrm{e}}\right)$ for the species was 0.095 (Table 2). Expected heterozygosity at each population ranged from 0.035 for $\mathrm{HM}$ to 0.133 for $\mathrm{HI}$, with a mean of 0.083 . The mean observed heterozygosity at the population level $\left(H_{\mathrm{o}}=0.079\right)$ was slightly lower than the expected heterozygosity $\left(H_{\mathrm{e}}=0.083\right)$. Inbreeding coefficients $\left(F_{\mathrm{IS}}\right)$ were determined for each population, and two relatively small populations (SS and $\mathrm{MB}$ ) showed relatively high $F_{\text {IS }}$ values. Randomization tests detected significant deficits of heterozygotes relative to Hardy-Weinberg expectations in the KK $\left(F_{\mathrm{IS}}=0.129\right)$ and $\mathrm{MB}\left(F_{\mathrm{IS}}=0.257\right)$ populations.

\subsection{Fixation indices and genetic differentiation pattern}

Significant genetic differentiations among populations were found for all polymorphic loci (Table 3 ). $F_{\mathrm{ST}}$ values for individual loci ranged from 0.020 (Sodh-2) to 0.203 (Aat-2) with a mean of 0.055 , and two loci for aspartate aminotransferase (Aat-1 and Aat-2) showed 7to 10 -fold higher $F_{\mathrm{ST}}$ values than the other loci, suggesting that the differentiation among populations is most evident in these two loci. In fact, the frequencies of dominant alleles (with highest frequencies in each locus) were strongly and positively related to the latitude of populations (linear regressions: $R^{2}=0.68, b=0.77$, $P=0.001$ for Aat $1 ; R^{2}=0.83, b=1.00, P<0.001$ for Aat-2), implying the presence of geographical clines. Significant values of $F_{\text {IT }}$ were observed in six loci, three of which (Adh-2, Sodh-2, and $G d h-2)$, however, were nearly equal to zero. Because these three loci actually hold very few polymorphisms, permutations could produce only a small variety of randomized sets of statistics and then failed to produce useful information (Goudet, 2000). Significantly positive $F_{\text {IT }}$ was observed when calculated for overall loci, indicating an overall excess of homozygotes (Table 4).

The NJ dendrogram of genetic distance among $T$. camschatcense populations (Fig. 2) clearly showed the genetic similarity of geographically adjacent populations. That is, the first major branch in the dendrogram separated the eight northern populations from the four southern populations, and the pattern obviously corresponds to the geographical pattern (Fig. 1). The grouping of northern and southern populations was supported by a high $(87 \%)$ bootstrap value. Consequently, we could classify the study populations geographically into two groups, the North group and the South group (Fig. 1; Table 1). Populations of the two groups are at least $34 \mathrm{~km}$ distant from each other, while the distances between populations within groups are less than $25 \mathrm{~km}$. Associations within each of the two regional groups exhibited some geographical patterning as well (Fig. 2). For example, the three populations 
Table 3

Number of alleles and Weir and Cockerham's (1984) estimates of Wright's $F$ statistics $\left(F_{\mathrm{IT}}, F_{\mathrm{ST}}, F_{\mathrm{IS}}\right)$, described for each polymorphic locus

\begin{tabular}{|c|c|c|c|c|}
\hline \multirow[t]{2}{*}{ Locus } & \multirow{2}{*}{$\begin{array}{l}\text { Number } \\
\text { of alleles }\end{array}$} & \multicolumn{3}{|l|}{$F$ statistics $^{\mathrm{a}}$} \\
\hline & & $F_{\text {IT }}$ & $F_{\mathrm{ST}}$ & $F_{\text {IS }}$ \\
\hline Aat-1 & 3 & $0.363(0.087)^{* * *}$ & $0.151(0.054)^{* * *}$ & $0.178(0.075)^{* * *}$ \\
\hline Aat-2 & 4 & $0.185(0.084)^{* * *}$ & $0.203(0.042)^{* * *}$ & $-0.022(0.074)$ \\
\hline$A d h-1$ & 3 & $0.049(0.057)$ & $0.024(0.010)^{* * *}$ & $0.026(0.061)$ \\
\hline Adh-2 & 2 & $-0.004(0.005)^{*}$ & $0.028(0.014)^{* * *}$ & $-0.032(0.014)$ \\
\hline Sodh-1 & 3 & $0.059(0.060)$ & $0.026(0.009)^{* * *}$ & $0.035(0.063)$ \\
\hline Sodh-2 & 2 & $-0.003(0.004)^{*}$ & $0.020(0.006)^{* * *}$ & $-0.024(0.004)$ \\
\hline$M d h-1$ & 3 & $0.056(0.059)$ & $0.023(0.008)^{* * *}$ & $0.033(0.063)$ \\
\hline$M d h-2$ & 2 & $0.498(0.003)^{* * *}$ & $0.025(0.008)^{* * *}$ & $0.485(0.003)^{* *}$ \\
\hline$G d h-1$ & 3 & $0.059(0.061)$ & $0.022(0.008)^{* *}$ & $0.038(0.066)$ \\
\hline$G d h-2$ & 2 & $-0.004(0.005)^{*}$ & $0.028(0.014)^{* * *}$ & $-0.032(0.014)$ \\
\hline
\end{tabular}

a Standard errors obtained by jackknifing are given in parentheses. *,**,** Significance for $F$ statistics obtained by randomization procedures $\left({ }^{*} P<0.05,{ }^{* *} P<0.01, * * * P<0.001\right)$.

Table 4

Weir and Cockerham's (1984) estimates of Wright's $F$ statistics $\left(F_{\mathrm{IT}}, F_{\mathrm{ST}}, F_{\mathrm{IS}}\right)$ and estimates of gene flow $(N m)$ based on $F_{\mathrm{ST}}$ calculated for overall populations and for each population group ${ }^{\mathrm{a}}$

\begin{tabular}{|c|c|c|c|c|}
\hline & $F_{\text {IT }}$ & $F_{\mathrm{ST}}$ & $F_{\mathrm{IS}}$ & $\mathrm{Nm}$ \\
\hline Overall populations & $0.191(0.161)^{* * *}$ & $0.130(0.040)^{* * *}$ & $0.070(0.068)^{* *}$ & 1.41 \\
\hline \multicolumn{5}{|l|}{ Within groups } \\
\hline North group & $0.068(0.022)^{* * *}$ & $0.031(0.008)^{* * *}$ & $0.038(0.020)$ & 5.98 \\
\hline South group & $0.151(0.195)^{* * *}$ & $0.025(0.030)^{* *}$ & $0.128(0.173)^{* *}$ & 5.48 \\
\hline
\end{tabular}

a Standard errors obtained by jackknifing are given in parentheses. ${ }^{* *},{ }^{* *}$ Significance for $F$ statistics obtained by randomization procedures (** $P<0.01, * * * P<0.001)$.

(MM, TN, and KK) with a low geographical separation clustered together. However, the bootstrap values within each of the two groups were not so high $(\sim 50 \%)$.

Although the level of genetic differentiation among overall populations was low $\left(F_{\mathrm{ST}}=0.130\right)$, much lower $F_{\mathrm{ST}}$ values for the North and South population groups were detected $\left(F_{\mathrm{ST}}=0.031\right.$ for the North, $F_{\mathrm{ST}}=0.025$ for the South; Table 4). Estimated gene flow within the same population groups $(\mathrm{Nm}=5.98$ for the North and $N m=5.48$ for the South) was much higher than the value for overall populations $(\mathrm{Nm}=1.41)$. Genetic distances among pairs of populations were low within the same population group, ranging from 0.001 to 0.008 for the North, and from 0.002 to 0.013 for the South, while genetic distances among the North and South groups ranged from 0.008 to 0.060 with a mean of 0.031 (data not shown).

\subsection{Relationships of population size to genetic diversity estimates}

The percentage of polymorphic loci $(P)$ and the mean number of alleles per locus $(A)$ had significant relationships with the $\log$ of population size (Fig. 3a and b), indicating that genetic variation was reduced in small populations. Three populations (SS, TB, and MB) with small population sizes ( $\leqslant 350$ flowering plants) exhibited low polymorphism $(P=18.2 \%)$ and low allelic richness $(A=1.18$ for SS and TB, 1.27 for MB). Of 28 alleles detected, $13(46 \%)$ were recognized as rare (frequency of $q<0.1$ ). When rare and common (frequency of $q \geqslant 0.1$ ) alleles are analysed separately as conducted in some studies (e.g. Prober and Brown, 1994; Young et al., 1999), all alleles that were not observed in small populations were rare, and the mean number of common alleles per locus was the same (1.18) for all populations (Fig. 3c). Populations with 350 flowering plants or fewer, in particular, had lost almost all of their rare alleles $(>93 \%)$. Observed heterozygosity $\left(H_{\mathrm{o}}\right)$, expected heterozygosity $\left(H_{\mathrm{e}}\right)$ and inbreeding coefficients $\left(F_{\mathrm{IS}}\right)$ had no relationship with the $\log$ of population size (Fig. 3d-f).

The association between population size and allelic richness was also corroborated by the simulation experiment. According to the simulations, larger populations were likely to be less affected by reducing sample sizes and showed larger allelic richness than those for small populations $(A=1.18)$ in most cases. Only two populations (HK and $\mathrm{HM}$ ) were severely reduced in their allelic richness to $A=1.18$ in approximately $50 \%$ of simulations. Although four populations $(\mathrm{OH}, \mathrm{KK}$, $\mathrm{PK}$, and $\mathrm{HI}$ ) experienced substantial losses of allelic richness, more than $90 \%$ of simulations were up to $19 \%$ losses of their allelic richness $(\mathrm{A} \geqslant 1.45$ for $\mathrm{OH} ; \mathrm{A} \geqslant 1.72$ 


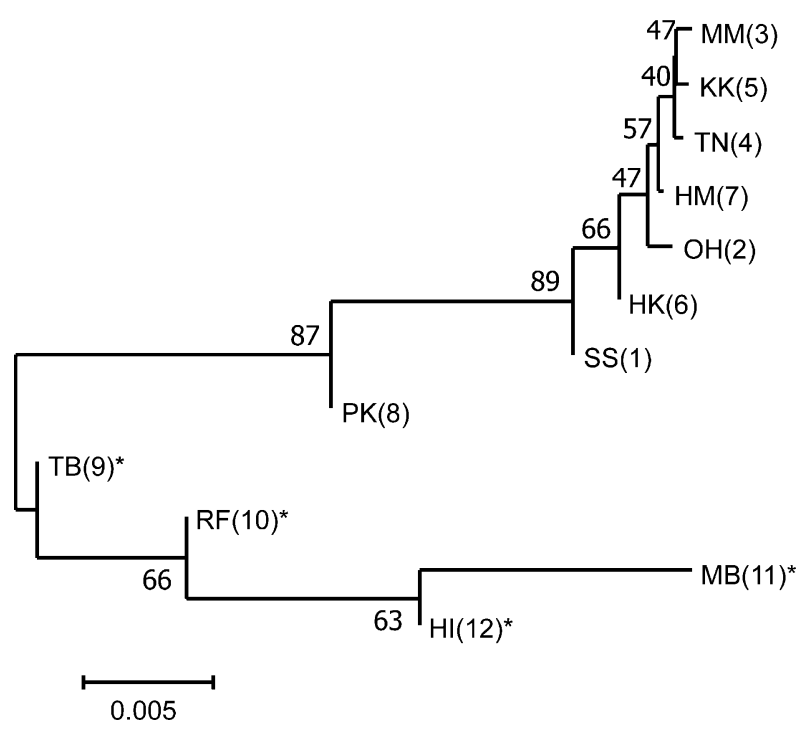

Fig. 2. Neighbor-joining (NJ) dendrogram (Saitou and Nei, 1987) of the genetic relationships among 12 Trillium camschatcense populations in the Tokachi region of Hokkaido, Japan, inferred from a matrix of standard genetic distance (Nei, 1972). Numbers in parentheses correspond to those in Table 1. Populations belonging to the South group (Fig. 1) are indicated with asterisks. Bootstrap values have been computed by resampling loci and are given as per cent values over 1000 replications.

for $\mathrm{KK}$; $\mathrm{A} \geqslant 1.55$ for $\mathrm{PK}$; $\mathrm{A} \geqslant 1.73$ for $\mathrm{HI}$; in $>90 \%$ of simulations). The other populations were not reduced in allelic richness in more than $90 \%$ of simulations. These results suggest that the association between population size and allelic diversity was substantive, not an artifact that the variation of sample sizes produced.

\section{Discussion}

\subsection{Effects of fragmentation on genetic diversity and levels of inbreeding}

Fragmented populations are predicted to experience stochastic loss of rare alleles first, because only a small portion of the original gene pool remains after fragmentation (reviews by Barrett and Kohn, 1991; Ellstrand and Elam, 1993; Young et al., 1996). Subsequently, random genetic drift will reduce allelic richness and increase interpopulation genetic divergence, however, it takes several generations for drift to have significant impacts. In study populations of $T$. camschatcense, at this time, only a few generations (probably one or two) have passed since fragmentation. On the other hand, elevated inbreeding induced by fragmentation can erode heterozygosity rapidly, leading to increased inbreeding coefficient.

Small, fragmented $T$. camschatcense populations have lost rare alleles that were expected to initially be present at low frequencies (Fig. 3c). Because the effects of drift were expected to be minor, the decrease in allelic richness in small populations was attributable to genetic bottlenecks at the time of fragmentation. The results indicate that populations are expected to lose 0.17 allelic richness for each reduction of their population size by $1 /$ 10 of the original [Fig. 3b; $A=1.00+0.17 \log$ (population size)]. Several studies have also shown a loss of rare alleles when populations were reduced in size for some perennial plant species, Salvia pratensis and Scabiosa columbaria (van Treuren et al., 1991), Eucalyptus albens (Prober and Brown, 1994), Gentiana pneumonanthe (Rajimann et al., 1994), Rutidosis leptorrhynchoides (Young et al., 1999), and Swainsona recta (Buza et al., 2000). On the other hand, population size should have little effect on expected heterozygosity (gene diversity), because alleles lost are mainly rare. As expected, we observed no significant relationship between expected heterozygosity and population size (Fig. 3e).

Although no effect of population size on observed heterozygosity and inbreeding coefficients was observed in the present study, inbreeding coefficients in some small populations were relatively high, and two populations (KK and $\mathrm{MB}$ ) showed significant deviations from Hardy-Weinberg expectations (Table 2). There are two possible explanations for this result. First, if population substructuring has affected sampling, inbreeding coefficients would be overestimated. That is, the patchy distribution of related individuals may generate a Wahlund effect. It was unlikely to explain the result, since fertile individuals seemed to be uniformly distributed within a small area. Second, significant amounts of inbreeding could occur within these populations. Fragmentation, coupled with localized pollinator movements and seed dispersal, may have resulted in significant biparental inbreeding, causing heterozygote deficiencies. Whereas the evidence of inbreeding was shown in some small populations, the $F_{\text {IS }}$ value of the smallest population (TB) did not differ from the Hardy-Weinberg expectation (Table 2). In this population, we found no seedling recruitment possibly because of low seed production and environmental deterioration (Tomimatsu and Ohara, in press). Some fertile plants may have survived fragmentation owing to the long life span of this species. Hence, the inbreeding coefficient of the TB population would only reflect the pre-fragmentation mating system, and relatively high $F_{\text {IS }}$ values in some small populations could reflect fragmentation. Further careful observation is needed to confirm whether pollination systems have changed after fragmentation by the comparison of pollinator fauna and their behavior to those of large and unfragmented populations.

\subsection{Local population structure}

The analyses of NJ dendrogram and $F$ statistics clearly showed the apparent genetic differentiation 

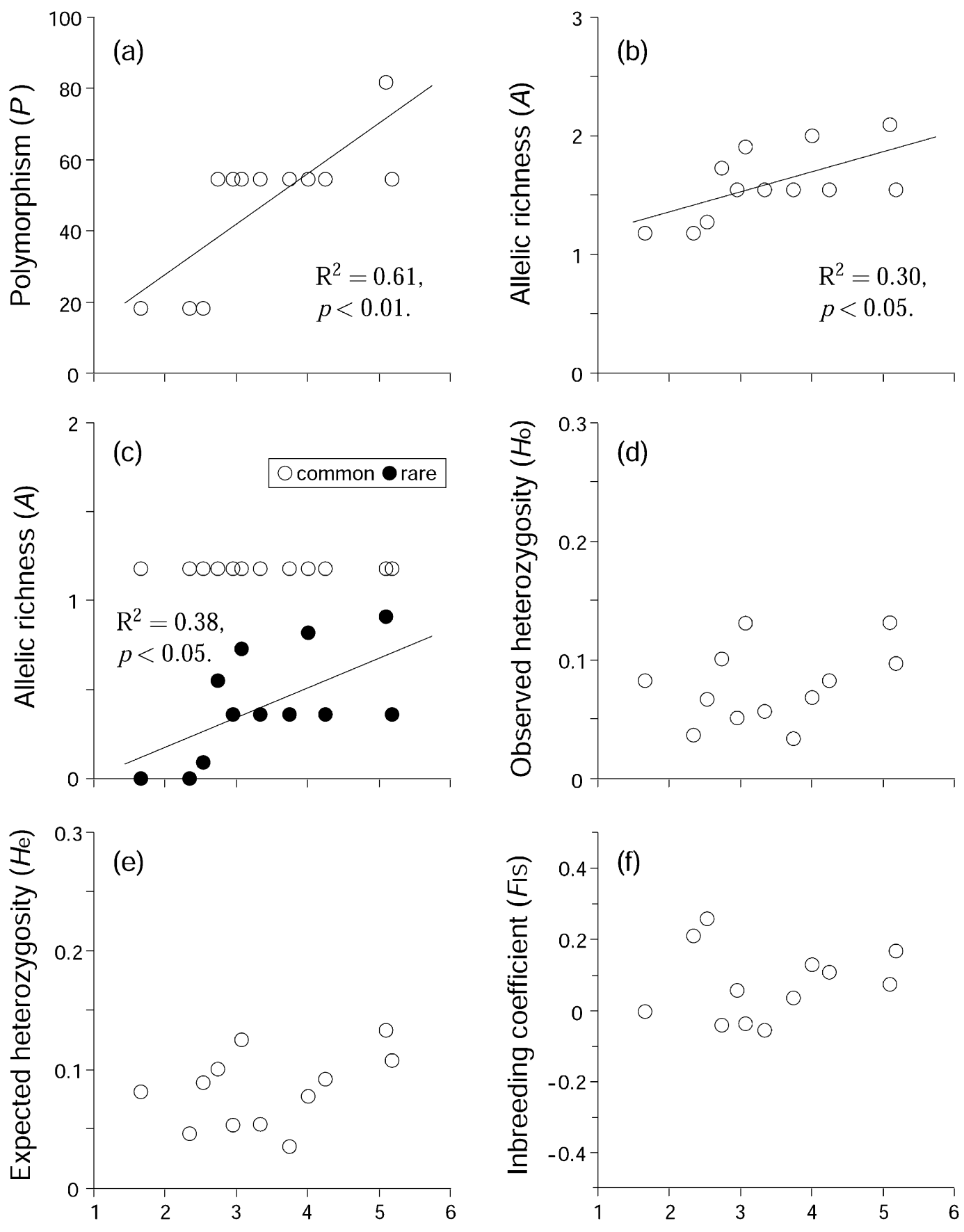

\section{$\log$ (population size)}

Fig. 3. Relationships between the log of population size (estimated number of flowering plants) and population genetics parameters; (a) percent polymorphic loci, (b) mean number of alleles per locus, (d) observed heterozygosity, (e) expected heterozygosity and (f) inbreeding coefficient. Leastsquare linear regressions are indicated in those cases where the slope of the regression line was significantly different from zero $(P<0.05)$. The relationship between population size and allelic richness for rare (closed circles; frequency of $q<0.1$ ) and common (open circles; frequency of $q \geqslant 0.1$ ) alleles are also shown (c).

between the two geographical groups (Fig. 2; Table 4). The pattern could have resulted from the low dispersal ability of this species and geographical separation. Pollinators of $T$. camschatcense are mostly small Diptera and Coleoptera species (Ohara et al., 1991; H. Tomimatsu et al., unpublished data) whose flight distances are thought to be relatively short. The seeds are dispersed by ants, whose dispersal distance was reported to be up to $3.3 \mathrm{~m}$ (Ohara and Higashi, 1987). The two groups are geographically separated by the small hills where this plant 
species is rarely found. The hills may be a barrier to gene flow and promote differentiation between groups. The earlier studies concerning the population genetics of T. camschatcense (Fukuda et al., 1960; Kozuka and Kurabayashi, 1960; Fukuda, 1990; Ohara et al., 1996) have mainly focused on wide range genetic differentiation within Hokkaido. They examined the patterns of genetic differentiations and possibilities of migration among and within three geographical groups in Hokkaido, first described by Kurabayashi (1957), to elucidate the genetic, ecological and paleogeographical forces producing the observed pattern. The present study indicated that significant interpopulation genetic differentiations have also occurred on a small, regional scale (within a radius of $30 \mathrm{~km}$ ). Such local population structure is of conservation concern for the maintenance of adaptive genetic variation (Crandall et al., 2000).

By contrast, the genetic differentiation within the two geographical groups was very low. The high level of gene flow estimates $(\mathrm{Nm})$ showed the possibility that there was a sufficient gene flow within groups (Table 4). However, $N m$ is a historical estimate under the assumption of migration-drift equilibrium (Wright, 1951). These estimates do not infer any pattern of ongoing gene flow and therefore any effects of fragmentation on gene flow. Ecological and genetic theory expects that gene flow rates, as measured by the fraction of immigrants per generation, increase as the size of the focal population decreases (Ellstrand and Elam, 1993). If the amount of pollen introduced from outside the populations remains invariant, the relative fraction of immigrant pollen grains or seeds increases (Handel, 1983). Indeed, recent experimental studies showed some evidence of a high gene flow rate among small and isolated populations (Young et al., 1993; Goodell et al., 1997). However, the expectation will not be applicable if the assumptions of the theory are not met, namely, if the amount of immigrant pollen varies among populations. This situation can occur when population isolation is greater than the foraging range of dispersers or when the availability of pollinators greatly differs among populations. Small T. camschatcense populations suffered low pollinator availability (Tomimatsu and Ohara, in press). Thus, the limited dispersal ability of this species and low pollinator availability in small populations may limit gene flow among these populations.

\subsection{Implications for conservation}

The results of this study suggest that reductions in population size have led to losses of rare alleles in small $T$. camschatcense populations. To retain high allelic diversity including many of rare alleles, populations with at least 550 flowering plants are required (Fig. 3c). At sizes below this, some elevation of inbreeding coefficient (Fig. 3f) and reduced seed production (Tomimatsu and Ohara, in press) also occurred. Because small populations will suffer from gradual effects of genetic drift, larger population sizes may be needed to avoid further allelic losses in the long term. In spite of the low level of genetic differentiation among overall populations, substantial genetic variations are those between the two geographically discontinuous population groups, which should attract management concern. The results showed the evidence of historical genetic unexchangeability, which may lead to a recommendation that the two geographical groups would be distinct evolutionarily significant units (ESUs; Moritz, 1994; Crandall et al., 2000) and be managed separately. Further information on other molecular markers and ecological distinctiveness will clarify appropriate management actions (Crandall et al., 2000).

The genetic deterioration may be related to remnant population viability. The loss of allelic variation may lower individual fitness, because the allelic richness of neutral molecular markers can be correlated with adaptive variations (Ouborg et al., 1991; Lynch et al., 1999). Young et al. (2000) showed that population size of Rutidosis leptorrhynchoides had a positive relationship with allelic variation at the self-incompatibility (S) locus, as well as allozyme diversity, indicating that reduced allelic variation was likely to reduce mate availability. This could also contribute to reduced seed production in small populations of $T$. camschatcense (Tomimatsu and Ohara, in press). In spite of its increasing need for species conservation, only a few studies have attempted to integrate immediate genetic effects of fragmentation into models of population viability (Burgman and Lamont, 1992; Menges and Dolan, 1998; Oostermeijer, 2000). Further study with a longterm field survey of demography will enable us to examine genetic effects on remnant population viability.

\section{Acknowledgements}

The authors are grateful to Shuji Oiki for technical support throughout the allozyme electrophoresis and Itsuro Koizumi, Jérôme Goudet, and anonymous reviewers for valuable comments on data analysis and on the manuscript. This study was supported by the Sasakawa Scientific Research Grant from the Japan Science Society, the Hokscitec Foundation, Grants-inAid from the JSPS for Scientific Research (10440230, 11691175, 13640637), and Research Fellowships of the JSPS for Young Scientists.

\section{References}

Aizen, M.A., Feinsinger, P., 1994. Forest fragmentation, pollination, and plant reproduction in a Chaco dry forest, Argentina. Ecology $75,330-351$. 
Barrett, S.C.H., Kohn, J.R., 1991. Genetic and evolutionary consequences of small population size in plants: implications for conservation. In: Falk, D.A., Holsinger, K.E. (Eds.), Genetics and Conservation of Rare Plants. Oxford University Press, New York, pp. 3-30.

Barton, N.H., Slatkin, M., 1986. A quasi-equilibrium theory of the distribution of rare alleles in a subdivided population. Heredity 56 , 409-415.

Burgman, M.A., Lamont, B.B., 1992. A stochastic model for the viability of Banksia cuneata populations: environmental, demographic and genetic effects. Journal of Applied Ecology 29, 719-727.

Buza, L., Young, A., Thrall, P., 2000. Genetic erosion, inbreeding and reduced fitness in fragmented populations of the endangered tetraploid pea Swainsona recta. Biological Conservation 93, 177-186.

Byers, D.L., 1995. Pollen quantity and quality as explanations for low seed set in small populations exemplified by Eupatorium (Asteraceae). American Journal of Botany 82, 353-359.

Crandall, K.A., Bininda-Emonds, O.R.P., Mace, G.M., Wayne, R.K., 2000. Considering evolutionary processes in conservation biology. Trends in Ecology and Evolution 15, 290-295.

Crow, J.F., Aoki, K., 1984. Group selection for a polygenic behavioral trait: estimating the degree of population subdivision. Proceedings of National Academy of Sciences of the United States of America 81, 6073-6077.

Ellstrand, N.C., Elam, D.R., 1993. Population genetic consequences of small population size: implications for plant conservation. Annual Review of Ecology and Systematics 24, 217-242.

Felsenstein, J., 1985. Confidence limits on phylogenies: an approach using the bootstrap. Evolution 39, 783-791.

Frankel, O.H., Brown, A.H.D., Burdon, J.J., 1995. The Conservation of Plant Biodiversity. Cambridge University Press, Cambridge.

Fukuda, I., 1990. Breeding systems in American and Asian Trillium species by means of chromosome analyses. Plant Species Biology 5, 65-72.

Fukuda, I., Hiraizumi, Y., Narise, T., Kurabayashi, M., 1960. Evolution and variation in Trillium. VI. Migrations among natural populations of $T$. kamtschaticum across the Ishikari depression. Evolution 14, 224-231.

Fukuda, I., Freeman, J.D., Itou, M., 1996. Trillium channelli, sp. nov. (Trilliaceae), in Japan, and T. camschatcense Ker Gawler, correct name for the Asiatic diploid Trillium. Novon 6, 164-171.

Goodell, K., Elam, D.R., Nason, J.D., Ellstrand, N.C., 1997. Gene flow among small populations of a self-incompatible plant: an interaction between demography and genetics. American Journal of Botany 84, 1362-1371.

Goudet, J., 2000. FSTAT, a program to estimate and test gene diversities and fixation indices (version 2.9.1). Available from http:// www.unil.ch/izea/softwares/fstat.html.

Handel, S.N., 1983. Pollination ecology, plant population structure, and gene flow. In: Real, L. (Ed.), Pollination Biology. Academic Press, Orlando, Florida, pp. 163-211.

Hamrick, J.L., Godt, M.J.W., 1996. Effects of life history traits on genetic diversity in plant species. Philosophical Transactions of the Royal Society of London, Series B 351, 1291-1298.

Jennersten, O., 1988. Pollination in Dianthus deltoides (Caryophyllaceae): effects of habitat fragmentation on visitation and seed set. Conservation Biology 2, 359-366.

Kozuka, Y., Kurabayashi, M., 1960. Evolution and variation in Trillium. VII. Migrations between northern and eastern population groups of T. kamtschaticum. Evolution 14, 232-237.

Kurabayashi, M., 1957. Evolution and variation in Trillium. IV. Chromosome variation in natural populations of Trillium kamtschaticum Pall. Japanese Journal of Botany 16, 1-45.

Lande, R., 1988. Genetics and demography in biological conservation. Science 241, 1455-1460.
Laurance, W.F., Ferreira, L.V., Rankin-de Merona, J.M., Laurance, S.G., 1998. Rain forest fragmentation and the dynamics of Amazonian tree communities. Ecology 79, 2032-2040.

Lovejoy, T.E., Bierregaard Jr., R.O., Rylands, A.B., Malcolm, J.R., Quintela, C.E., Harper, L.H., Brown Jr., K.S., Powwell, A.H., Powell, G.V.N., Schubart, H.O.R., Hays, M.B., 1986. Edge and other effects of isolation on Amazon forest fragments. In: Soulé, M.E. (Ed.), Conservation Biology: the Science of Scarcity and Diversity. Sinauer Associates, Sunderland, Massachusetts, pp. 257-285.

Lynch, M., Pfrender, M., Spitze, K., Lehman, N., Hicks, J., Allen, D., Latta, L., Ottene, M., Bogue, F., Colbourne, J., 1999. The quantitative and molecular genetic architecture of a subdivided species. Evolution 53, 100-110.

Menges, E.S., Dolan, R.W., 1998. Demographic viability of populations of Silene regia in midwestern prairies: relationships with fire management, genetic variation, geographic location, population size and isolation. Journal of Ecology 86, 63-78.

Moritz, C., 1994. Defining 'Evolutionarily Significant Units' for conservation. Trends in Ecology and Evolution 9, 373-375.

Nei, M., 1972. Genetic distance between populations. American Naturalist 106, 283-292.

Ohara, M., Kawano, S., 1986a. Life history studies on the genus Trillium (Liliaceae) I. Reproductive biology of four Japanese species. Plant Species Biology 1, 35-45.

Ohara, M., Kawano, S., 1986b. Life history studies on the genus Trillium (Liliaceae) IV. Stage class structures and spatial distribution of four Japanese species. Plant Speices Biology 1, 147-161.

Ohara, M., Higashi, S., 1987. Interference by ground beetles with the dispersal by ants of seeds of Trillium species (Liliaceae). Journal of Ecology 75, 1091-1098.

Ohara, M., Okazaki, K., Kawano, S., 1991. Predominant inbreeding and resource limitation in four Japanese Trillium species. Miyabea 1, 21-30.

Ohara, M., Takeda, H., Ohno, Y., Shimamoto, Y., 1996. Variations in the breeding system and the population genetic structure of Trillium kamtschaticum (Liliaceae). Heredity 76, 476-484.

Oostermeijer, J.G.B., 2000. Population viability analysis of the rare Gentiana pneumonanthe: the importance of genetics, demography and reproductive biology. In: Young, A.G., Clarke, G.M. (Eds.), Genetics, Demography and Viability of Fragmented Populations. Cambridge University Press, Cambridge, pp. 313-334.

Oostermeijer, J.G.B., van Eijck, M.W., van Leeuwen, N.C., den Nijs, J.C.M., 1995. Analysis of the relationship between allozyme heterozygosity and fitness in the rare Gentiana pneumonanthe L. Journal of Evolutionary Biology 8, 739-759.

Ota, T., 1993. DISPAN: Genetic Distance and Phylogenetic Analysis. The Pennsylvania State University, University Park, PA.

Ouborg, N.J., van Treuren, R., van Damme, J.M.M., 1991. The significance of genetic erosion in the process of extinction. II. Morphological variation and fitness components in populations of varying size of Salvia pratensis L. and Scabiosa columbaria L. Oecologia 86, 359-367.

Prober, S.M., Brown, A.H.D., 1994. Conservation of the grassy white box woodlands: population genetics and fragmentation of Eucalyptus albens. Conservation Biology 8, 1003-1013.

Rajimann, L.E.L., van Leeuwen, N.C., Kersten, R., Oostermeijer, J.G.B., den Nijs, H.C.M., Menken, S.B.J., 1994. Genetic variation and outcrossing rate in relation to population size in Gentiana pneumonanthe L.. Conservation Biology 8, 1014-1026.

Saitou, N., Nei, M., 1987. The neighbor-joining method: a new method for reconstructing phylogenetic trees. Molecular Biology and Evolution 4, 406-425.

SAS Institute, 1997. SAS Version 6.12. SAS Institute, Cary, North Carolina.

Schemske, D.W., Husband, B.C., Ruckelshaus, M.H., Goodwillie, C., Parker, I.M., Bishop, J.G., 1994. Evaluating approaches to the conservation of rare and endangered plants. Ecology 75, 584-606. 
Sherwin, W.B., Moritz, C., 2000. Managing and monitoring genetic erosion. In: Young, A.G., Clarke, G.M. (Eds.), Genetics, Demography and Viability of Fragmented Populations. Cambridge University Press, Cambridge, pp. 9-34.

Shiraishi, S., 1988. Inheritance of isozyme variations in Japanese black pine, Pinus thunbergii Parl. Silvae Genetica 37, 93-100.

Slatkin, M., 1985. Rare alleles as indicators of gene flow. Evolution 39, 53-65.

Slatkin, M., Barton, N.H., 1989. A comparison of three indirect methods for estimating average levels of gene flow. Evolution 43, $1349-1368$.

Tan, Y., 1994. Present condition of the forest islands in Obihiro. Report of the Obihiro Centennial City Museum 12, 1-8. (in Japanese with English summary).

Tomimatsu, H., Ohara, M. Effects of forest fragmentation on seed production of the understory herb Trillium camschatcense. Conservation Biology, 16 (in press).

van Treuren, R., Bijlsma, R., van Delden, W., Ouborg, N.J., 1991. The significance of genetic erosion in the process of extinction. I. Genetic differentiation in Salvia pratensis and Scabiosa columbaria in relation to population size. Heredity 66, 181-189.
Weir, B.S., Cockerham, C.C., 1984. Estimating F-statistics for the analysis of population structure. Evolution 38, 1358-1370.

Wright, S., 1951. The genetical structure of populations. Annals of Eugenetics 15, 313-345.

Young, A., Boyle, T., Brown, T., 1996. The population genetic consequences of habitat fragmentation for plants. Trends in Ecology and Evolution 11, 413-418.

Young, A.G., Merriam, H.G., Warwick, S.I., 1993. The effects of forest fragmentation on genetic variation in Acer saccharum Marsh. (sugar maple) populations. Heredity 71, 277-289.

Young, A.G., Merriam, H.G., Brown, A.H.D., Zich, F.A., 1999. Genetic structure of fragmented populations of the endangered daisy Rutidosis leptorrhynchoides. Conservation Biology 13, 256265.

Young, A.G., Merriam, H.G., Murray, B.G., Thrall, P.H., Miller, C.H., 2000. Genetic erosion, restricted mating and reduced viability in fragmented populations of the endangered grassland herb Rutidosis leptorrhynchoides. In: Young, A.G., Clarke, G.M. (Eds.), Genetics, Demography and Viability of Fragmented Populations. Cambridge University Press, Cambridge, pp. 335-359. 